\title{
Şəbəkə Mühitində Elektron Texniki Xidmətin Təşkili Məsələləri
}

\author{
Təhmasib Fətəliyev ${ }^{1}$, Şakir Mehdiyev ${ }^{2}$ \\ ${ }^{1,2}$ AMEA İnformasiya Texnologiyaları İnstitutu, Bak1, Azərbaycan \\ Idepart3@iit.ab.az,22depart11@iit.ab.az
}

\begin{abstract}
Xülasə- Məqalədə e-elmin fasiləsiz və etibarlı fəaliyyətinə dəstək olan e-texniki xidmət sisteminin yaradılması məsələlərinə baxılmıșdır. Bu sahədə beynəlxalq təcrübə araşdırılmış və müvafiq təkliflər verilmişdir.
\end{abstract}

Açar sözlor-e-elm, e-xidmotlor, proqram tominatı, e-texniki xidmot

\section{GIRIS}

Respublikada "Elektron Azərbaycan"1n tərkib hissəsi kimi həyata keçiriləne-elm ərazicə paylanmıș infrastruktura malikdir və AzScienceNet elm kompüter şəbəkəsi əsasında formalaşır. Elmi fəaliyyət və elmin idarə olunmasında İKT-nin geniş tətbiqi məqsədini daşıyan e-elm müxtəlif təyinatlı çoxlu sayda texniki və proqram vasitələrindən təşkil olunmuşdur [1]. Həmin vasitələrə düzgün və keyfiyyətli texniki xidmətin təşkil olunması e-elmin səmərəliyinin artırılmasını təmin edir.

Texniki avadanlıqların etibarlılığı, az enerji sərfiyyatı, yüksək keyfiyyəti və təhlükəsizliyi, onlara çəkilən xərclərin aşağı olması kimi məsələlərə istehsalçı və istifadəçilər həmişə diqqət etmişlər. Elm və texnikanın inkişafı digər sahələrdə olduğu kimi öz növbəsində maşın və avadanlıqlara edilən ənənəvi texniki xidmətlərin yeni vasitələrinin yaradılmasına səbəb olmuşdur. Son onilliklər ərzində tədqiq və tətbiq olunan elektron texniki xidmət (e-texniki xidmət)bu sahənin aktual yeniliyidir.

Təqdim edilən işdə mürəkkəb texniki struktura malik olan e-elmin fasiləsiz və etibarlı fəaliyyətinə dəstək məqsədi ilə onun elektron texniki xidmət (e-texniki xidmət) sisteminin işlənməsi məsələlərinə baxılmışdır.

\section{ELEKTRON TEXNIKİ XIDMӘT SISTEMI}

E-elmin ən vacib resursu sayılan informasiyanın keyfiyyəti tamlıq, düzgünlük, aktuallıq, təhlükəsizlik və saxlanma etibarlılığı kimi metrikalarla xarakterizə olunur. Qarşıya qoyulmuş bu məsələlərə nail olmaq üçün e-elmin maksimal etibarlı işi təmin edilməlidir. Belə ki, sistemin işində səhvlər və müvəqqəti durğunluq müxtəlif növ (bəzən isə qarşısı alına bilinməyən) itkilərlə nəticələnə bilər. Bu halda, texniki xidmət və təmir (TXT) vasitəsilə həyata keçirilən etibarlılığın sazlıq, təmirə yararlılıq, qoruna bilmə, davamlılıq kimi xassələrini təmin etmək zəruridir. TXT sisteminin əsas məlum strategiyalarını nəsərdən keçirək [2]:

- Reactive Maintenance - Nasazlıq hadisəsinə texniki xidmət;

- Preventive Maintenance - Planl1-xəbərdaredici və ya reqlamentə görə texniki xidmət;
- Condition Based Maintenance, Condition Moni-toring Maintenance vo ya Predictive Maintenance - Faktiki vəziyyətə görə xidmət. Ölçü texniki vasitələrilə avadanlığın real vəziyyətinin monitorinqi və diaqnostikasını nəzərdə tutur və bundan sonra riyazi aparat əsasında gələcək profilaktik və təmir işlərinin məqsədəuyğunluğu haqqında proqnoz verilir;

- Proactive Maintenance-Profilaktik və ya fəal texniki xidmot;

- Reliability Centered Maintenance - Etibarlılıq yönümlü xidmot.

TXT strategiyaları çərçivəsində fəaliyyət növlərini aşağıdakı kimi klassifikasiya etmək olar:

- texniki xidmət;

- cari təmir;

- əsasli təmir;

- modernləşdirmə;

- yeni avadanlığın dəyişdirilməsi və quraşdırılması.

- AMEA-da e-elmin istismarıtəcrübəsi göstərir ki, İKT ilə əlaqədar ən çox göstərilən xidmətlər bunlardır:

- proqram təminatının (əməliyyatsistemləri, tətbiqi proqramlar və s.) quraşdırılması, sazlanması, bərpa edilməsi və parametrlərinin optimallaşdırılması;

- aparat və proqram uyğunsuzluqlarının aradan qaldırılması;

- sərt disklərə müntəzəm xidmət;

- verilənlərin ehtiyat nüsxəsinin alınması və bərpası;

- nasazlıqların aşkarlanması və aradan qaldırılması;

- virusların aradan qaldırılması;

- kompüterlərə, noutbuklara, serverlərə və s. texniki yardım (təmir və modernləşdirilmə);

- İnternetə qoşulmanın sazlanması;

- kommunikasiya avadanlığının sazlanması;

- periferiya qurğularının quraşdırılması;

- profilaktik işlər. 
Müasir İKT-nin, İnternetin, xüsusi ilə Veb 2.0 və Đşyaların İnterneti texnologiyalarının vəonlar əsasında formalaşan onlayn əməkdaşlıq vasitələrininimkanlarıtexniki xidmət sahəsində $e$ texniki xidmət (eMaintenance) adlanan yeni anlayışı yaratmışdır. Ona texniki ədəbiyyatda ilk dəfə 2000-ci illərin əvvəllərində rast gəlinir və hazırda çox geniş yayılmışdır $[3,4]$. Araşdırmalar e-texniki xidmətin yeni bir texnologiya kimi formalaşmasını, bu sahədə aparılan elmi-tədqiqat və praktiki işlərin miqyasının artmasını göstərir.

Dünyanın məşhur çap avadanlıqlarının istehsalçısı Canon[5] və təyyarə istehsalçısı Dassault Falcon[6] kompaniya-larının bu sahədə gördüyü işlərlə tanış olaq. Belə ki, Canonistehsal etdiyi printerlər üçün "eMaintenance" xidmətini təklif edir (şəkil 1). Onun bu xidməti uzaq məsafədə quraşdırılmış Canon cihazlarına nəzarət edir. Hər hansı bir səhv baş verirsə və ya cihaz tələb olunan standartlara uyğun işləmirsə, onda Canon və ya tərəfdaş e-poçt vasitəsilə dərhal və avtomatik olaraq məlumatlandırılır.Dassault Falcon-nun "Falcon eMaintenance" xidməti uzaqdan təyyarələrin Mərkəzi texniki xidmətinin kompüterinə daxil olmaqla diaqnostika aparmaq vo nasazlıqları aradan qaldırmaq imkanlarına malikdir.

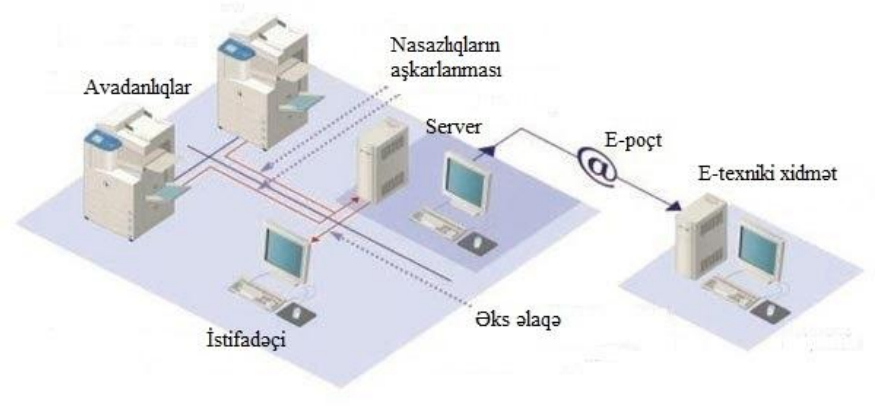

- Şəkil 1.Canon-une Maintenance xidməti

Beləliklə, beynəlxalqvə AMEA-da e-elmin istismarı təcrübəsi mövcud texniki xidmət sisteminin müasir tələblərə uyğun təkmilləşdirilməsini zəruri edir. Yaradılan sistemeelminsəmərəli işinin təmin olunmasındaaşağıdakı üstünlüklərlə xarakterizə oluna bilər:

- onlayn fasiləsiz smart xidmət;

- istifadəçi və istehsalçı arasında birbaşa əlaqə imkanı;

- resurslarin avtomatik monitorinqi;

- nəzarat və profilaktikanın operativliyi;

- resurs yönümlü proqnozların avtomatik həyata keçirilməsi və $\mathrm{s}$.

\section{E-TEXNIKI XIDMӘT SİSTEMININ E-ELMӘ DӘSTӘYI}

Elmi fəaliyyət və elmin idarə olunmasının müasir tələblər səviyyəsində inkişafının təmin olunması üçün kommunikasiyaşəbəkə və hesablama infrastrukturunun formalaşdırılmasıeelmin əsas vəzifəsidır. Bu istiqamətdə aparılmış işlərin nəticəsi kimi e-elmin şəbəkə platforması olan AzScienceNet və böyük hesablama və yaddaş resurslarına malik olan Verilənlərin
Emalı Mərkəzi yaradılmışdır. E-elmin şəbəkə platforması olan AzScienceNet AMEA-nın bütün elmi müəssisələrini əhatə edir, ona qoşulmuş fərdi kompüter və kompüter avadanlıqlarının sayı 6500-dən çox və İnternetə çıxış sürəti $1.5 \mathrm{~Gb} / \mathrm{san}$.-dir. Verilənlərin Emalı Mərkəzi 500 Terabayt yaddaş və hesablama məhsuldarlığı isə 17 Tflops olan texniki xarakteristikaya malikdir. Fəaliyyətdə olan bu şəbəkə və hesablama einfrastrukturu elmi qurumlar arasında sürətli əlaqə yaradır, istifadəçilərə e-elmin çoxsaylı xidmətlərini (hostinq, AzCloud, AzStorage, e-poçt, e-kitabxana, distant təhsil, AzScienceCERT, eduroam və s.) təqdim edir və eyni zamanda Beynəlxalq şəbəkələrlə inteqrasiya imkanları yaradır[1].

Beləliklə, belə böyük texniki xarakteristikalara malik olan e-elmə mürəkkəb bir sistem kimi baxmaq və onu infrastruktur, verilənlərin toplanması, saxlanması, emalı, axtarışı, analizi, ötürülməsi, təqdim olunması və s. kimi müxtəlif təyinatlı texniki və proqram vasitələrinə ayırmaqolar (şəkil 2).

E-elm platformasinda e-texniki xidmət sisteminin yaradılmasında əsas məqsəd e-elmin qeyd olunmuş mürəkkəb tərkib hissələrini təşkil edən texniki və proqram vasitələrinin etibarlı, səmərəli və fasiləsiz işçi vəziyyətinin təmin olunmasıdır.Bu məqsədə nail olunmas1 sistemin profilaktika, nəzarət, diaqnostika, nasazlıqların aşkarlanması, lokallaşdırılması, proqnozlaşdırılması, qarşısının alınması və bərpası kimi funksiyaları ilə həyata keçirir.

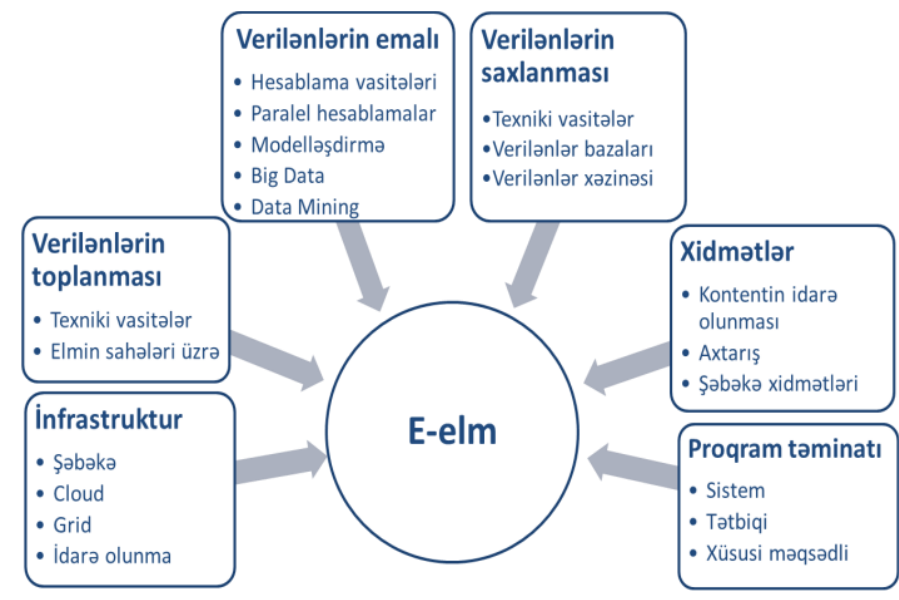

Şəkil 2. E-elmin tərkib hissələri

Qeyd etmək lazımdır ki, e-texniki xidmət sistem və proqram mühəndisliyinin tələblərinə cavab verən mürəkkəb bir sistemdir. O, ərazi cəhətdən paylanmış infrastruktura malikdir. Mürəkkəb analitik-informasiya sistemlərinə xas olan kommunikasiya, verilənlərin toplanması, saxlanması,emalı və intellektual analizi vasitələrindən təşkil olunur. Onun texniki vasitələrə birbaşa təsir və istifadəçilərə dəstək əks əlaqə mexanizmləri vardır.

\section{NӘTİCӘ}

Müxtəlif təyinatlı çoxlu sayda texniki və proqram vasitələrindən təşkil olunmuş e-elmin səmərəli və fasiləsiz işinin təmin olunması mürəkkəb və aktual məsələdir. Müasir İKT-nin inkişafı, xüsusi ilə Veb 2.0 və Đşyaların İnterneti texnologiyalarının meydana gəlməsitexniki xidmət sahəsində mühüm yeniliklərə gatirmiş̧ir. $\mathrm{Bu}$ istiqamətdə aparılmış 
araşdırmalar e-elm platformasında e-texniki xidmət sisteminin yaradılmasının vacibliyini təsdiq edir.

\section{ӘDӘВIYYAT}

[1] R.M.Alguliyev,R.Q. Alakbarov, T.Kh.Fataliyev,.Electronic science: current status, problems and perspectives, Problems of information technology, 2015, №2, pp.4-14.

[2] Sh.A. Mehdiyev,Computer system maintenance in a corporate environment, Problems of information technology, 2017, №1, p.84-90.

[3] E.Levrat, B Iung, A. Crespo Marquez,E-maintenance: review and conceptual framework. Production Planning \& Control, Vol. 19, №4, June 2008, pp. 408-429.
[4] M.Ucar, R.G. Qiu,E-Maintenance in support of e-automated manufacturing systems, Journal of the Chinese Institute of Industrial Engineers, 2005, Vol. 22, №1, p.1-10.

[5] Intelligent Remote Device management, www.canon.com.au/enau/Business/Software-Solutions/Service/eMaintenance

[6] Dassault to Provide Cutting Edge Support Through Falcon 'EMaintenance', www.dassaultfalcon.com

$\mathrm{Bu}$ iș Azarbaycan Respublikasının Prezidenti yanında Elmin İnkişafi Fondunun maliyya yardımı ilo yerina yetirilmişdir - Qrant № EİF-2014-9(24)-KETPL-14/02/1 